\title{
Scaling Resistance in Nanophotonics-Enabled Solar Membrane Distillation (SI)
}

\author{
Douglas Rice ${ }^{1,2}$, Shahrouz J Ghadimi ${ }^{2,3}$, Ana C. Barrios ${ }^{1,2}$, Skyler Henry ${ }^{2}$, W. Shane \\ Walker ${ }^{2,3}$, Qilin $\mathrm{Li}^{2,4}$, François Perreault ${ }^{1,2^{*}}$ \\ ${ }^{1}$ School of Sustainable Engineering and the Built Environment, Arizona State University \\ ${ }^{2}$ Nanosystems Engineering Research Center for Nanotechnology-Enabled Water \\ Treatment \\ ${ }^{3}$ Department of Civil Engineering, University of Texas at El Paso \\ ${ }^{4}$ Department of Civil and Environmental Engineering, Rice University
}

Summary

$\begin{array}{ll}\text { Cover page } & \text { S1-S2 } \\ \text { Materials and Methods } & \text { S3-S4 }\end{array}$

Figure S1 S5

Figure S2 S6

Figure S3 S7 
Figure S4

Table S1

Table S2

Table S3

References
S8

S9

S10-11

S12

S13 


\section{Materials and Methods}

Materials: All chemicals were obtained from Sigma Aldrich (Saint Louis, MO), except as noted below. CB NPs were provided by Cabot (Boston, MA). N-methyl-4(4'formylstyryl)pyridinium methosulfate acetal (PVA- SbQ) was obtained from Polysciences (Warrington, PA). Magnesium sulfate heptahydrate $(98+\%)$ and glycerol $(99+\%)$ were supplied by Acros Organics (Geel, Belgium). Calcium chloride dihydrate $(99.5+\%)$ was provided by G-Biosciences (Saint Louis, MO). Sodium bicarbonate (99+\%) was supplied by Fisher Scientific (Hampton, NH). Feed spacers (19 mils, polypropylene) were kindly donated by Conwed Plastics LLC (Minneapolis, MN).

Membrane characterization: Contact angles were measured with an Attension Theta (Biolin Scientifin, Gothenburg, Sweden) using a 1001 TPLT Hamilton syringe (Reno, NV). Contact angle data was used to determine hydrophilicity and surface free energy (SFE) of each material. Nanopure water was used for water contact angles (WCA), while the solvents used to solve for the SFE were nanopure water, diiodomethane, and glycerol. For both WCA and SFE at least 5 different measurements were taken. SFE was calculated in accordance to the OWRK/Fowkes equation. ${ }^{1}$ Surface zeta potential was evaluated by streaming potential measurements with a ZetaCAD analyzer with a flat surface cell (CAD Instruments, Les Essarts-le-Roi, France). An electrolyte solution composed of $5 \mathrm{mM} \mathrm{KCl}$ and $0.1 \mathrm{mM} \mathrm{HCO}_{3}$ was used for the measurements. Measurements were done for a $\mathrm{pH}$ range of 3-10 to identify the point of zero charge of each material. Surface roughness was analyzed by atomic force microscopy (AFM) with a Bruker MultiMode 8 AFM (Bruker, Billerica, MA). The topographical images were taken in peak force tapping mode with 
NCHV cantilevers with a spring constant of $42 \mathrm{~N} / \mathrm{m}$ (Bruker, Camarillo, CA). Image analysis was done using the Nanoscope Analysis version 1.7 software.

MD and NESMD experimental set up: Cole Palmer gear pumps (Vernon Hills, IL) were used to deliver water, and a Precision Scientific hot water bath (Chicago, IL) was used to heat the feed water through glass coils. A Thermo Scientific Orion Versa Star Pro electrochemistry meter measured the conductivity of the permeate and a Sartorius Cubis scale (Goettingen, Germany) measured water flux.

Data analysis and statistics: Means and standard deviations were estimated for each treatment. Comparison between treatments was done with a Student's t-test, with $p$-values less than 0.05 considered to be significant. 


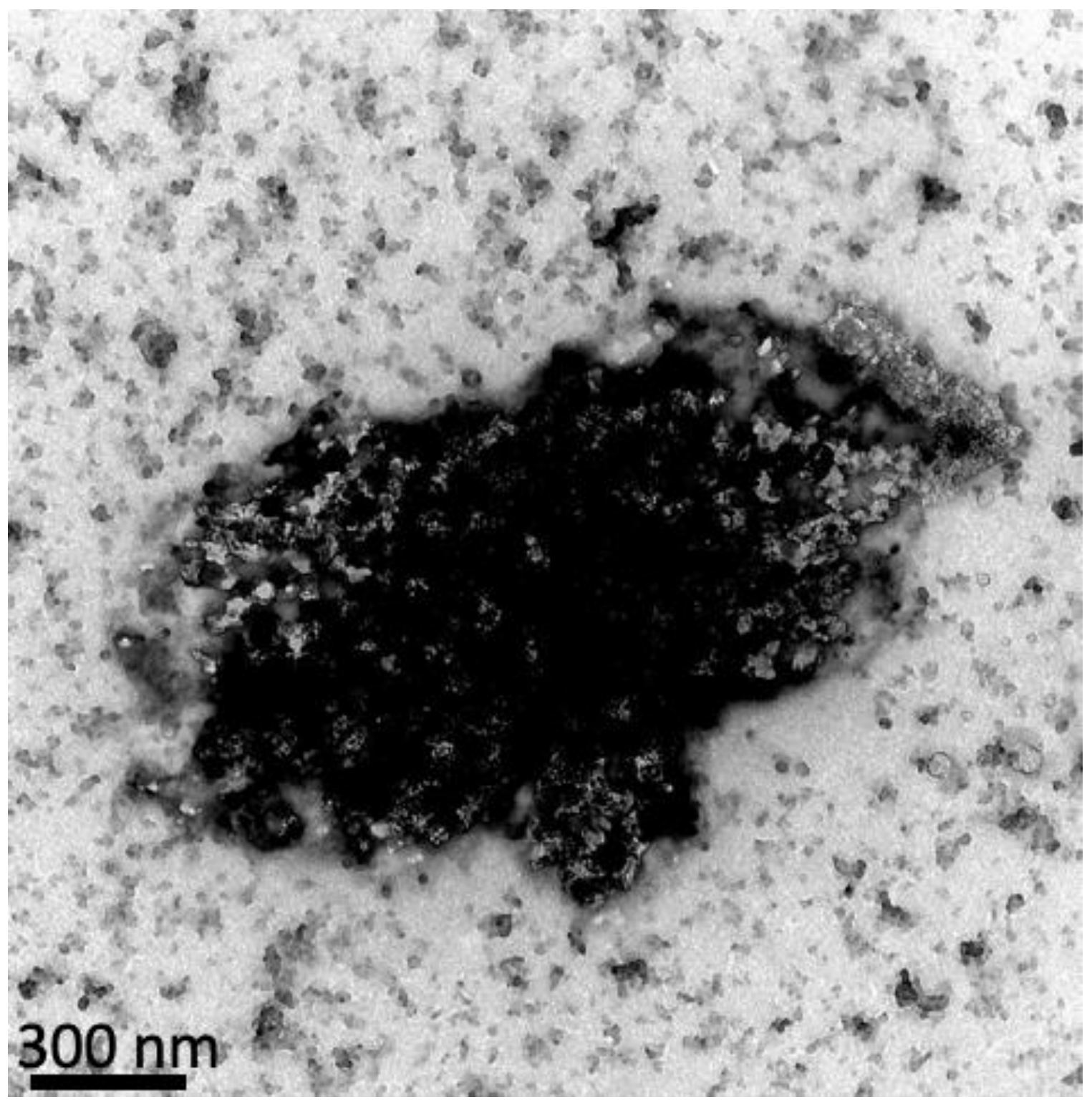

Figure S1: TEM image of carbon black nanoparticles. The dispersed particles show an average particle diameter of $d_{a v e}=40.0 \mathrm{~nm} \pm 24.3 \mathrm{~nm}$. A large aggregate is seen at the center of the picture due to drying of the suspension during TEM sample preparation. Pictures were taken using a Philips CM12 TEM operated at 80kV and equipped with a Gatan model 791 CCD camera. 


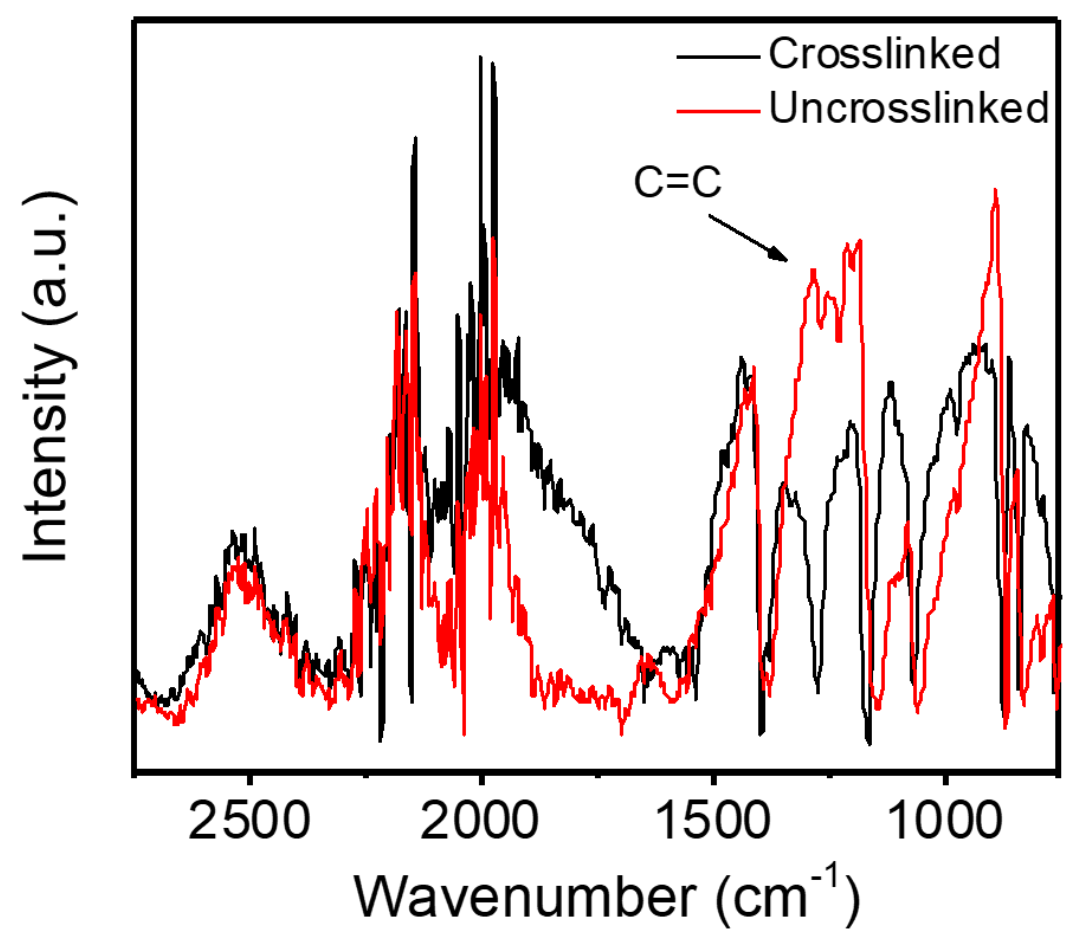

Figure S2: FTIR spectra of uncrosslinked (red) and crosslinked (black) CB-PVDF membrane. The $\mathrm{C}=\mathrm{C}$ peak observed at $1256 \mathrm{~cm}^{-1}$ is weakened due to the photocrosslinking of PVA-SbQ. ${ }^{2}$ 


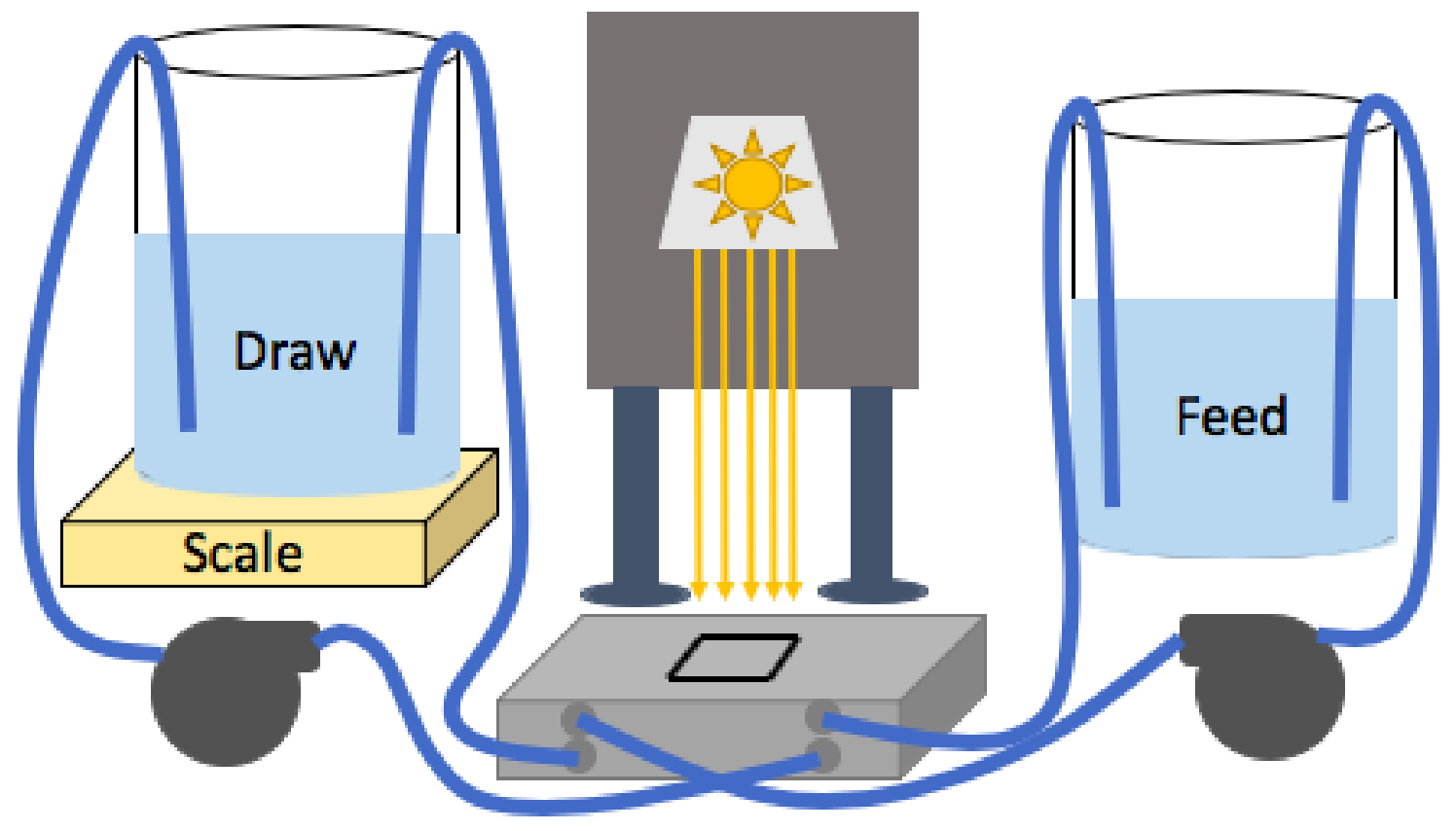

Figure S3: Experimental set up of NESMD system. 


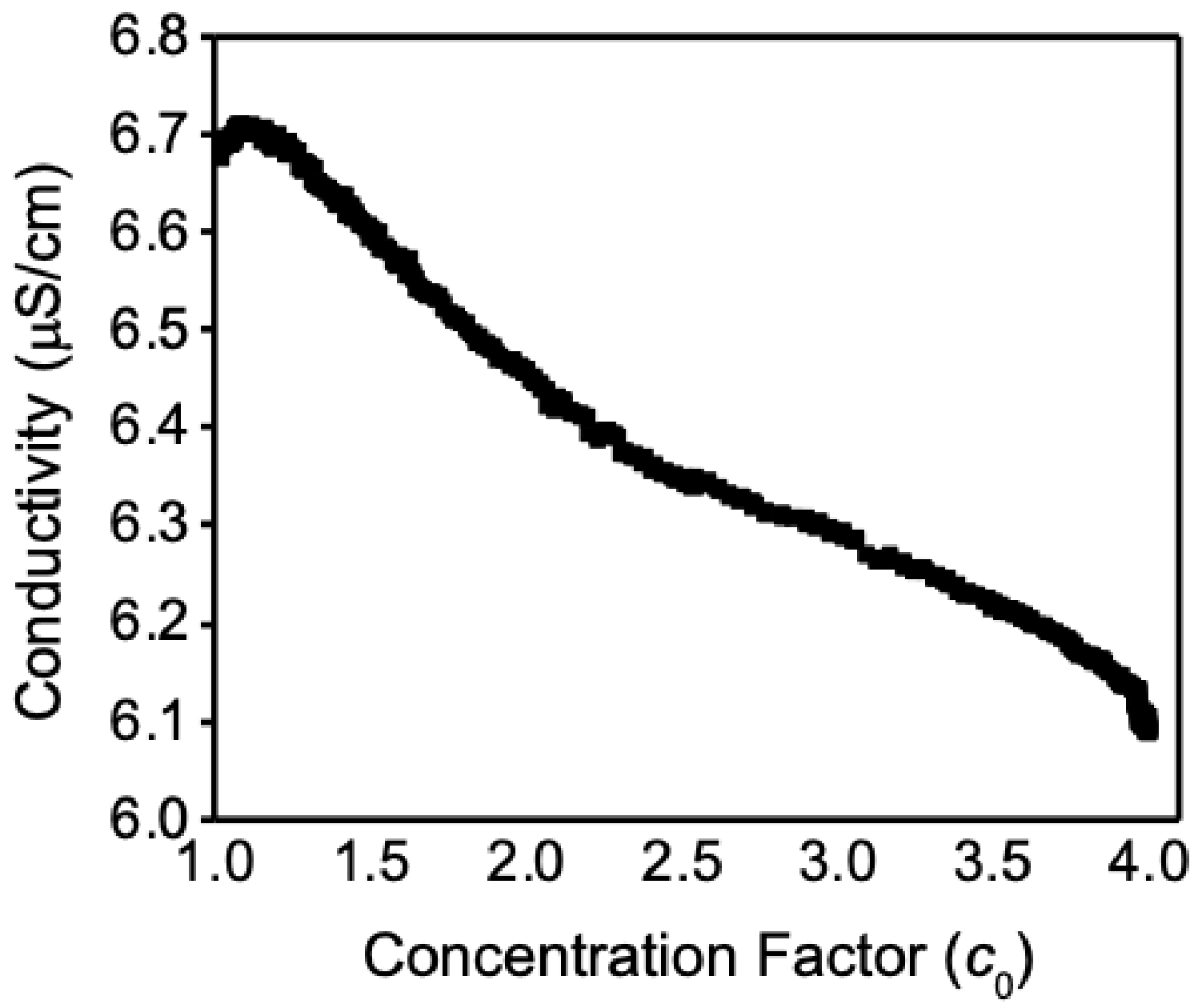

Figure S4: Conductivity decline of permeate as increasing volumes of freshwater are produced from the feed. 
Table S1: Model brackish groundwater based on the aquifers of the Southwestern United States. The $\mathrm{pH}$ was adjusted to 7.5 at the start of the trial.

\begin{tabular}{|c|c|c|}
\hline Constituent & Concentration $(\mathbf{m g} / \mathbf{L})$ & Concentration $(\mathbf{m M})$ \\
\hline Bicarbonate $\left(\mathrm{HCO}_{3}{ }^{-}\right)$ & 930 & 15.2 \\
\hline Calcium $\left(\mathrm{Ca}^{2+}\right)$ & 1,070 & 26.7 \\
\hline Chloride $\left(\mathrm{Cl}^{-}\right)$ & 3,299 & 10.7 \\
\hline Magnesium $\left(\mathrm{Mg}^{2+}\right)$ & 260 & 63.1 \\
\hline Sodium $\left(\mathrm{Na}^{+}\right)$ & 1,450 & 14.8 \\
\hline Sulfate $\left(\mathrm{SO}_{4}{ }^{-}\right)$ & 1,420 & - \\
\hline Total Dissolved Solids & 8,429 & 223.6 \\
\hline Ionic Strength & - & \\
\hline
\end{tabular}


Table S2: Equilibrium modeling values of salt precipitation for NESMD and MD systems at various concentration factors.

\begin{tabular}{|c|c|c|}
\hline $\begin{array}{l}\text { Salt and Concentration } \\
\text { Factor }\left(c_{0}\right)\end{array}$ & $\begin{array}{l}\mathrm{mM} \text { of Precipitation } \\
\left(\mathrm{NESMD}\left(\Delta \mathrm{T}=0^{\circ} \mathrm{C}\right)\right)\end{array}$ & $\begin{array}{l}\text { mM of Precipitation } \\
\left(\mathrm{MD}\left(\Delta \mathrm{T}=40^{\circ} \mathrm{C}\right)\right)\end{array}$ \\
\hline Calcite 1 & 4.39 & 5.50 \\
\hline Gypsum 1 & 0 & 0 \\
\hline Dolomite 1 & 0 & 0 \\
\hline Calcite 1.5 & 7.57 & 8.99 \\
\hline Gypsum 1.5 & 2.58 & 1.55 \\
\hline Dolomite 1.5 & 0 & 0 \\
\hline Calcite 2 & 10.9 & 13.0 \\
\hline Gypsum 2 & 9.24 & 7.83 \\
\hline Dolomite 2 & 0 & 0 \\
\hline Calcite 3 & 17.9 & 18.9 \\
\hline Gypsum 3 & 23.2 & 21.9 \\
\hline Dolomite 3 & 0 & 0.56 \\
\hline Calcite 4 & 17.1 & 18.7 \\
\hline Gypsum 4 & 39.2 & 37.6 \\
\hline
\end{tabular}




\begin{tabular}{|c|c|c|}
\hline Dolomite 4 & 4.24 & 5.31 \\
\hline Calcite 5 & 15.9 & 17.9 \\
\hline Gypsum 5 & 55.8 & 54.0 \\
\hline Dolomite 5 & 8.23 & 9.23 \\
\hline Calcite 6 & 14.7 & 17.4 \\
\hline Gypsum 6 & 72.5 & 70.6 \\
\hline Dolomite 6 & 13.0 & 14.0 \\
\hline
\end{tabular}


Table S3: Initial flux rates of the different conditions used in this study.

\begin{tabular}{|c|c|}
\hline Condition & Flux $\left(\mathbf{L} / \mathbf{m}^{\mathbf{2}} \mathbf{- h}\right)$ \\
\hline Regular MD $\left(\Delta \mathrm{T}=40^{\circ} \mathrm{C}\right)$ & $43.2 \pm 4.84$ \\
\hline NESMD $\left(\Delta \mathrm{T}=0^{\circ} \mathrm{C}\right)$ & $0.755 \pm 0.216$ \\
\hline Regular MD $\left(\Delta \mathrm{T}=10^{\circ} \mathrm{C}\right)$ & $0.810 \pm 0.103$ \\
\hline NESMD $\left(\Delta \mathrm{T}=10^{\circ} \mathrm{C}\right)$ & $0.861 \pm 0.129$ \\
\hline Slow Crossflow $\mathrm{MD}\left(\Delta \mathrm{T}=40^{\circ} \mathrm{C}\right)$ & $37.6 \pm 4.24$ \\
\hline Low $\beta$ MD $\left(\Delta \mathrm{T}=4^{\circ} \mathrm{C}\right)$ & $0.693 \pm 0.329$ \\
\hline
\end{tabular}




\section{References}

(1) Owens, D. K.; Wendt, R. C. Estimation of the surface free energy of polymers. Journal of Applied Polymer Science 1969, 13, 1741-1747.

(2) Tao, Y.; Ai, L.; Bai, H.; Liu, X. Synthesis of pH-Responsive Photocrosslinked Hyaluronic Acid-Based Hydrogels for Drug Delivery. 2012, No. I, 3507-3516. 